\title{
Taxonomic and conservation implications of ecological speciation in Nesospiza buntings on Tristan da Cunha
}

\author{
PETER G. RYAN
}

\section{Summary}

In addition to protecting species, conservation also includes the maintenance of evolutionary processes, but this aspect is often overlooked. Nesospiza buntings provide a good case study of the need to conserve evolutionary processes. They are endemic to the South Atlantic Tristan da Cunha archipelago, and traditionally have been treated as two species, with each having different subspecies on Nightingale and Inaccessible Islands. Both species are listed as Vulnerable because of their small ranges $\left(<20 \mathrm{~km}^{2}\right)$ and the threat posed by the possible introduction of alien organisms such as mice or rats. The two species differ markedly in size, especially bill size, related to dietary differences. However, recent research suggests that morphological diversity evolved independently on Nightingale and Inaccessible Islands, necessitating a revision of the taxonomy within the genus. I recommend that five taxa be recognized, with two endemic to Nightingale and three to Inaccessible Island. N. wilkinsi and N. questi on Nightingale are welldefined species, but there is considerable hybridization between taxa on Inaccessible Island. These three taxa may be incipient species, but are perhaps best treated as subspecies: N. acunhae acunhae, N. a. dunnei and N. a. fraseri (nom. nov.). All three species qualify as threatened, with $N$. acunhae and N. questi Vulnerable and N. wilkinsi Endangered. With fewer than 200 individuals, $N$. wilkinsi has one of the smallest natural populations of any bird. A reassessment of its population size is a conservation priority, following the 2001 storm that damaged many Phylica trees on Nightingale Island. Improved biosecurity quarantine measures are also needed for Nightingale Island. Care should be taken not to disrupt the natural processes occurring among bunting taxa on Inaccessible Island.

\section{Introduction}

Despite calls for system-wide conservation that allows for the maintenance of evolutionary processes, most emphasis is still placed on species-level conservation (Collar 1997). The threat status assigned to species using the IUCN Red List criteria remains important in conservation decision-making, and changes in the numbers and status of listed species provides a tool for evaluating the success of conservation actions (BirdLife International 2004). As a result, conservation priorities may be influenced by taxonomic decisions. This paper discusses the conservation implications of an intriguing example of ecological speciation among a group of island birds. This requires a revision of the group's taxonomy and provides a case study where the conservation of evolutionary processes is perhaps as important as the conservation of currently defined taxa.

Nesospiza buntings are confined to a few small islands in the Tristan da Cunha archipelago in the central South Atlantic Ocean. They evolved from finch-tanagers (Thraupini) that reached the islands after travelling across 3,000 km of ocean from South America (Rand 1955, Ryan et al. 
2007). Nesospiza has been regarded as a classic example of a simple adaptive radiation (Lack 1947, Abbott 1978), with two species on Nightingale and Inaccessible Islands. The Tristan Bunting N. acunhae is an abundant, small-billed dietary generalist feeding on seeds of grasses and sedges as well as various invertebrates, whereas Wilkin's or Grosbeak Bunting N. wilkinsi is a rare, large-billed specialist, feeding mainly on the woody fruit of the only native tree Phylica arborea (Lowe 1923, Hagen 1952, Elliott 1957). Tristan Buntings used to occur on the main island of Tristan, but went extinct during the nineteenth century, following the introduction of mice and other alien organisms (Hagen 1952). A large-billed form is not known to have occurred on Tristan. Given their small ranges $\left(<20 \mathrm{~km}^{2}\right)$ and the continuing risk of accidental introduction of mammalian predators to their islands, both species are listed as Vulnerable (BirdLife International 2004).

Size differences between populations of both small- and large-billed birds on Nightingale and Inaccessible Islands led to them being recognized as distinct subspecies (Lowe 1923, Hagen 1952). However, recent research indicates that morphological diversity has evolved independently on each island (Ryan et al. 2007). Two species occur on Nightingale Island, where there is a single habitat with strongly bimodal seed size abundance. Three lineages occur on Inaccessible Island, linked to the greater diversity of habitats (Ryan et al. 1994), but segregation is incomplete, due either to continuing speciation or to an equilibrium between selection and recurrent hybridization (Ryan et al. 2007). These findings require a revision of the taxonomy within Nesospiza and, linked to this, a reassessment of their threat status using the IUCN Red List criteria.

\section{Discovery and naming of Nesospiza}

Tristan da Cunha is a small archipelago of volcanic islands in the central South Atlantic Ocean (Figure 1). The three main islands, $20-35 \mathrm{~km}$ apart, differ in size and age. Tristan is the largest $\left(96 \mathrm{~km}^{2}\right)$ and youngest island (approximately 200,00o years old), Nightingale is the smallest (4 $\mathrm{km}^{2}$ ) and oldest island (up to 18 million years), whereas Inaccessible is intermediate in size (14 $\mathrm{km}^{2}$ ) and age (3-6 million years; Ollier 1984). The main island of Tristan is the only inhabited island, with a community of some 280 people. It was settled in the early 1800 , resulting in the introduction of numerous alien animals and plants, including Black Rat Rattus rattus and House Mouse Mus musculus (Wace and Holdgate 1976). Fewer alien species have become established on the two smaller islands, which are free of introduced mammals (Wace and Holdgate 1976, Ryan and Glass 2001).

Ryan et al. (1994) summarized the history of Nesospiza collections. Dupetit Thouars (1811) reported a bunting from the main island of Tristan in 1793, and it was first collected in 1817 (Carmichael 1818). It was subsequently named Nesospiza acunhae by Cabanis (1873), with the type specimen housed in the Humboldt Museum, Berlin. The only other specimen collected at Tristan was taken in 1842 by Brierly (Wace and Holdgate 1976), but the fate of this specimen is unknown. Carmichael (1818) reported the bird to be "plentiful" in 1817 , but it had become "uncommon" by 1852 (Bourne and David 1981) and was either very rare or extinct when HMS Challenger visited in 1873 (Moseley 1892).

Buntings were collected on Nightingale and Inaccessible Islands for the first time in 1873 by Moseley during the Challenger visit (Moseley 1892). Additional specimens were collected by Wilkins during the visit of the Quest in 1922 (Lowe 1923). Both expeditions collected a single large-billed bird, with Moseley taking one from Inaccessible and Wilkins one from Nightingale. These were described as a novel species by Lowe (1923), using Wilkins' specimen as the type. Lowe (1923) also recognized that the small-billed birds from Nightingale were smaller than birds from Inaccessible and named them N. a. questi. During the Norwegian Scientific Expedition of 1937-1938, Hagen (1952) was the first biologist to spend more than a few hours with the birds in the field. He collected a series of skins of both small- and large-billed birds from Inaccessible and Nightingale in 1938, and described the large-billed birds from Inaccessible Island as a new 


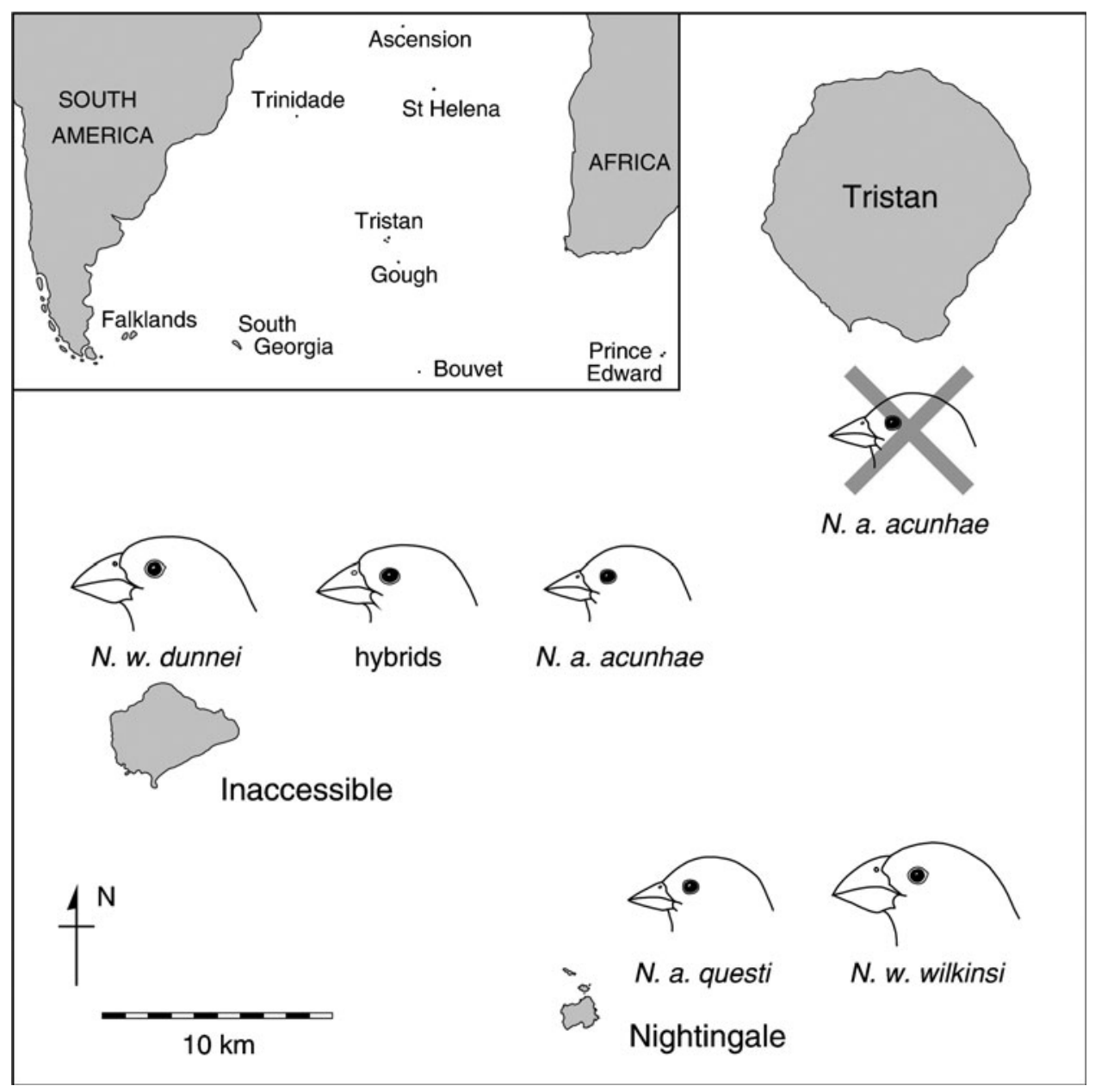

Figure 1. The Tristan da Cunha archipelago, central South Atlantic Ocean, showing the distribution of Nesospiza populations under the traditional taxonomy. Buntings went extinct on the main island of Tristan during the nineteenth century.

subspecies N. w. dunnei based on their smaller size than birds from Nightingale. He also noted the nomenclatural problem created by the implicit assumption that the Inaccessible population of small-billed birds is identical to the Type from Tristan (see also Elliott 1957).

Subsequent visits by naturalists added little to our knowledge of the diversity of buntings, especially on Inaccessible Island, because few people reached the eastern plateau where hybridization is frequent (Ryan et al. 1994). Richardson (1984) examined the small-billed birds on Stoltenhoff and Alex (Middle), the two large islets off the north coast of Nightingale, and found them to be identical to $N$. a. questi. Large-billed birds were not found on either islet (Richardson 1984). Abbott (1978) reviewed the morphological diversity based on museum skins to test ecological predictions based on competition theory. However, he failed to consider the large-billed form from Inaccessible $N . w$. dunnei, which he regarded as rarer than $N$. w. wilkinsi based on a liberal interpretation of Elliott (1957).

It was only in 1982/3, during the Denstone Expedition, that Mike Fraser discovered the occurrence of two colour morphs of small-billed buntings at Inaccessible Island (Collar and 
Stuart 1985, Fraser and Briggs 1992). Subsequent fieldwork in 1987-1990 confirmed subtle morphological differences between these morphs, linked to differences in their diet, and discovered the presence of widespread hybridization between small- and large-billed forms on the eastern plateau (Ryan 1992, Ryan et al. 1994). Tables 1 and 2 summarize the range of morphological variation found on the two islands, based on 723 birds measured in the field during 1988-1990, 1999-2000 and 2004 (all measurements made by P.G.R.). These data exclude 183 birds from the eastern plateau of Inaccessible Island, where there is widespread introgression between lineages, as well as 19 birds of apparent hybrid origin between small- and large-billed forms in adjacent habitats. It is beyond the scope of this paper to fully explore the morphological variation found among apparent hybrids on Inaccessible Island. Outside the eastern plateau, almost all birds can be readily assigned to one of the three taxa on the basis of morphology and plumage colour. All five taxa differ significantly in wing length when compared within same-sex groups (Table 1), and only small-billed taxa between islands fail to differ significantly in bill length (Table 2). Restricting comparisons to the three lineages on Inaccessible Island, all differ, with $P<0.001$ for both wing and culmen measures (Tukey test after one-way ANOVA).

The proportion of apparent hybrids between small- and large-billed birds (based on intermediate morphology) caught outside the eastern plateau of Inaccessible is inflated because of directed sampling towards "odd" birds. However, it is still small, with only three hybrids caught in coastal Spartina tussock ( $0.7 \%$ of birds caught) and 16 in Blechnum palmiforme heath on the western plateau $(7.7 \%)$. Only one lowland Tristan Bunting was caught on the plateau edge, in an area dominated by upland buntings. Nine upland birds were caught on the coast, but they were all immature birds caught in spring and early summer. It appears that some immature upland birds move onto the coast to feed in winter (Ryan et al. 1994).

Table 1. Differences in wing length ( $\mathrm{mm}$ ) among Nesospiza taxa (excludes birds from Phylica woodland on the eastern plateau of Inaccessible and 19 apparent hybrids from outside this habitat).

\begin{tabular}{|c|c|c|c|}
\hline \multirow[t]{2}{*}{ Island } & \multirow[t]{2}{*}{ Taxon } & \multirow{2}{*}{$\frac{\text { Males }^{a}}{\text { Mean } \pm \text { SD }(n)}$} & \multirow{2}{*}{$\begin{array}{l}\text { Females }^{b} \\
\text { Mean } \pm \text { SD }(n)\end{array}$} \\
\hline & & & \\
\hline \multirow[t]{3}{*}{ Inaccessible } & N. a. dunnei & $95.26 \pm 1.35(39)$ & $91.20 \pm 1.41(44)$ \\
\hline & N. a. acunhae & $85.97 \pm 1.50(200)$ & $82.89 \pm 1.58(125)$ \\
\hline & N. a. fraseri & $87.37 \pm 1.56($ (102) & $84.33 \pm 1.45$ (90) \\
\hline \multirow[t]{2}{*}{ Nightingale } & N. questi & $82.71 \pm 1.52(62)$ & $79.91 \pm 1.41(23)$ \\
\hline & N. wilkinsi & $100.32 \pm 1.00(19)$ & $97.26 \pm 1.97$ (19) \\
\hline
\end{tabular}

aANOVA $F_{4,417}=832.6, P<0.001 ;$ Tukey test all taxa differ $P<0.001$.

${ }^{\mathrm{b}}$ ANOVA $F_{4,295}=620.7, P<0.001$; Tukey test all taxa differ $P<0.001$.

Table 2. Differences in bill length (mm) among Nesospiza taxa (excludes birds from Phylica woodland on the eastern plateau of Inaccessible and 19 apparent hybrids from outside this habitat).

\begin{tabular}{|c|c|c|c|}
\hline \multirow[t]{2}{*}{ Island } & \multirow[t]{2}{*}{ Taxon } & Males $^{a}$ & Females $^{b}$ \\
\hline & & Mean \pm SD $(n)$ & Mean \pm SD $(n)$ \\
\hline \multirow[t]{3}{*}{ Inaccessible } & N. a. dunnei & $18.07 \pm 0.48$ & $17.88 \pm 0.49(44)$ \\
\hline & N. a. acunhae & $14.94 \pm 0.52(200)$ & $14.51 \pm 0.49(125)$ \\
\hline & N. a. fraseri & $14.50 \pm 0.37(102)$ & $14.23 \pm 0.44(90)$ \\
\hline \multirow[t]{2}{*}{ Nightingale } & N. questi & $14.71 \pm 0.30(62)$ & $14.23 \pm 0.37(23)$ \\
\hline & N. wilkinsi & $19.55 \pm 0.30(19)$ & $19.11 \pm 0.36(19)$ \\
\hline
\end{tabular}

${ }^{a}$ ANOVA $F_{4,417}=925.7, P<0.001$; Tukey test all taxa differ $P<$ o.001, except acunhae vs questi $(P<0.01)$ and fraseri vs questi $(P<0.05)$.

${ }^{\mathrm{b}}$ ANOVA $F_{4,295}=908.8, P<0.001$; Tukey test all taxa differ $P<0.001$, except acunhae vs questi $(0.05<P$ $<$ o.I) and fraseri vs questi (NS). 


\section{A new taxonomy for Nesospiza}

Contrary to previous studies, Ryan et al. (2007) reported that both mitochondrial and nuclear genes indicate that the main difference among Nesospiza buntings is between island populations, rather than between small- and large-billed forms (Figure 2). The most parsimonious explanation for these genetic differences is that small- and large-billed forms have evolved independently on each island through parallel ecological speciation. Even if initial segregation occurred in allopatry, with the similarity between taxa within islands a function of subsequent introgression, the taxa on each island have distinct evolutionary histories. Accordingly, they should be regarded as distinct species (McKitrick and Zink 1988, Zink 1997).

Despite having identical sequences of the mitochondrial gene cytochrome $b$, small- and largebilled forms on Nightingale Island are well differentiated in terms of morphology and nuclear markers (Ryan et al. 2007). The two taxa have quite different songs and are not known to interbreed (Ryan 1992, P. G. Ryan unpubl. data). Hybrids among Nesospiza are intermediate in size (Ryan 2001) and are readily identified in the field on Inaccessible, where the size difference between large- and small-billed birds is less than on Nightingale (Table 2). No hybrids have been recorded among 124 birds handled $(n=38$ large-billed and 86 small-billed birds) and many more observed on Nightingale Island. Thus I recommend recognizing two species on Nightingale Island:

Nesospiza questi Lowe 1923 - Nightingale Bunting, and

Nesospiza wilkinsi Lowe 1923 - Wilkins' Bunting.

The situation on Inaccessible Island is more complex (Ryan et al. 1994, 2007). Nuclear microsatellite data support the recognition of three lineages, but they are not completely sorted (Ryan et al. 2007), with extensive hybridization on the eastern plateau between all three lineages (Ryan et al. 1994). Given the limited genetic differentiation and range of intermediate phenotypes, it is perhaps best to recognize only a single species. Notwithstanding the confusion regarding the relationship between the population on Inaccessible and the type from Tristan, I suggest that the population on Inaccessible remain as N. acunhae but with a new common name: Inaccessible Bunting. Within this species, three lineages can be recognized. They are perhaps best treated as subspecies. The subspecies rank has come under scrutiny recently, in part because

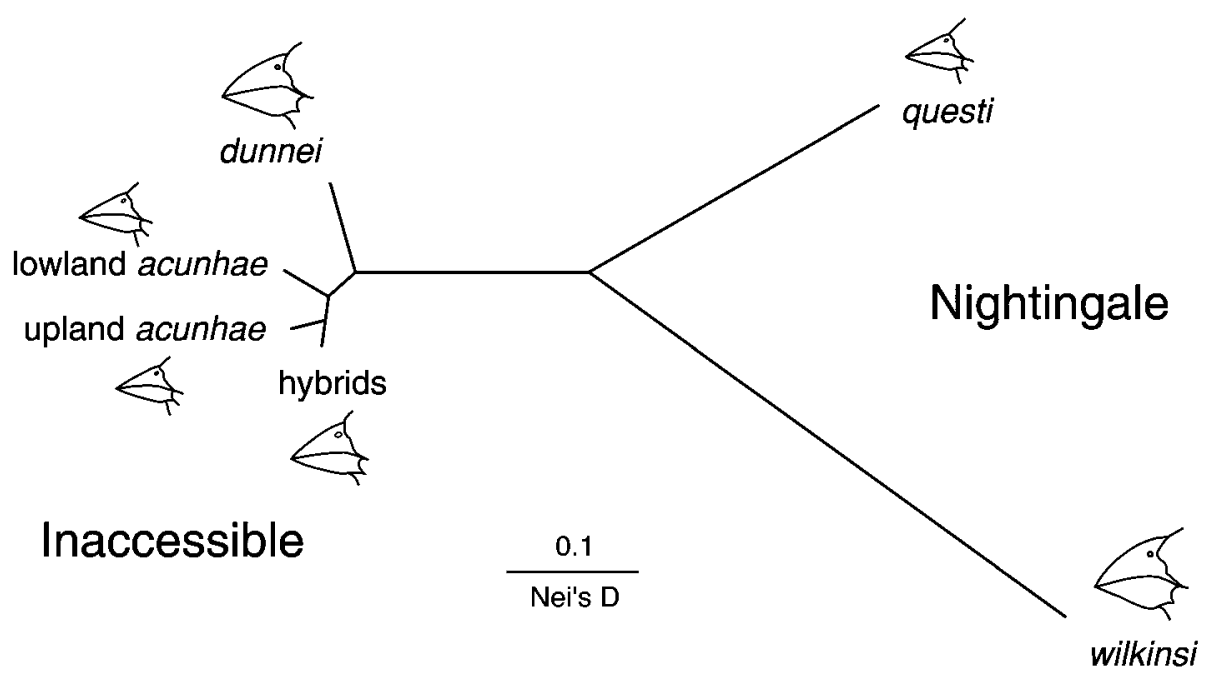

Figure 2. Relationships among Nesospiza taxa inferred from allelic diversity in seven microsatellites (adapted from Ryan et al. 2007). Taxon names follow the proposed taxonomy for the genus. 
many subspecies fail to reflect genetically distinct populations (Zink 2004, Phillimore and Owens 2006), but this criticism fails to apply in this case. The three bunting lineages on Inaccessible probably are in a state of flux, but it is expedient to identify them as subspecies because the majority of birds on the island can be ascribed to one of the three lineages. Subspecies names also provide convenient labels for the three main phenotypes. The Type of acunhae from Tristan most closely resembles a drab, lowland bunting in terms of plumage, and thus I propose:

Nesospiza a. acunhae Cabanis 1873 - Lowland Inaccessible Bunting,

Nesospiza a. fraseri (nom. nov.) - Upland Inaccessible Bunting, and

Nesospiza a. dunnei Hagen 1952 - Dunn's Inaccessible Bunting.

N. a. fraseri is named after M. W. Fraser, who first discovered the occurrence of a brightly coloured "upland" form of small-billed bunting on Inaccessible Island. Its distinctive plumage, described by Fraser and Briggs (1992), apparently results from the greater abundance of carotenoids in its diet (Ryan et al. 1994). Despite this difference being environmentally induced, the colour morphs breed assortatively, with few mixed pairs at the ecotone between tussock grassland and plateau vegetation (Ryan 1992). Contrary to the comments in Fraser and Briggs (1992), the two small-billed forms differ subtly in morphology, with the upland form having on average a slightly larger body (Table 1 ) and smaller bill (Table 2). The type is designated as BMNH reg. no. 1998.70.1, an adult female with two eggs in oviduct, collected on the island plateau above North Point on II December 1982 by M. W. Fraser.

\section{Population size and conservation status}

Currently, both species of Nesospiza are listed as Vulnerable because of their small ranges (criterion $\mathrm{D}_{2}$ ) and, in the case of Wilkins' Bunting, small population size (D1; BirdLife International 2004). Their susceptibility to extinction was demonstrated by the demise of buntings on the main island of Tristan within a century of human colonization. The exact causes of this extinction are unknown. The population decrease started well before the introduction of rats in 1882 (Wace and Holdgate 1976), and indeed they may already have been extinct before rats arrived. Hagen (1952) suggested that the bunting's disappearance may have been linked to the loss of tussock grass Spartina arundinacea from the coastal lowlands, but much natural vegetation remains on the cliffs and 'base' of Tristan (the lower slopes of the island's volcanic peak) that is superficially similar to the habitat occupied by buntings on the plateau of Inaccessible Island. Also, substantial areas of tussock remained on the southern coastal plain of Tristan until after 1900 (Barrow 1910). Predation of eggs and chicks by introduced mice, which probably arrived at the island well before rats, may account for the extinction at Tristan. Mouse predation has been implicated in the relatively low densities of Gough Buntings Rowettia goughensis on nearby Gough Island (Cuthbert and Hilton 2004). Feral cats, now extinct on Tristan, may also have contributed to the bunting's demise; some were present on the island in the early nineteenth century (Wace and Holdgate 1976). Rodents or other mammalian predators would pose a serious threat to the buntings should they reach Inaccessible or Nightingale islands.

The revision to Nesospiza taxonomy requires a reassessment of their conservation status. The Inaccessible Bunting N. acunhae qualifies as Vulnerable under criterion D2 (very small range), given its total range of only $14 \mathrm{~km}^{2}$. It is abundant, especially in coastal tussock. On the west coast around Blenden Hall, Lowland Buntings breed at densities of some 15 pairs ha ${ }^{-1}$, and cooccur with up to 2-3 pairs ha ${ }^{-1}$ of Dunn's Buntings where there are Phylica copses (Ryan 1992). Buntings are less abundant at higher elevations, with up to $6-7$ pairs ha $^{-1}$ of Upland Buntings on the western plateau and 4 pairs $\mathrm{ha}^{-1}$ of hybrids on the eastern plateau (Ryan 1992). This extrapolates to a population of some 7,000 pairs of Lowland Buntings and 200 pairs of Dunn's Buntings in coastal tussock, 2,500 pairs of Upland Buntings, and 2,00o pairs of 'hybrids' (Ryan 1992). The distribution of hybrid phenotypes on the eastern plateau varies with the abundance of Phylica fruit (Ryan et al. 2007). 
The situation on Nightingale Island is less complex, with two well-defined species. Nightingale Buntings are abundant. Richardson (1984) estimated 500-1,000 pairs on Nightingale, 40-80 pairs on Alex or Middle Island, and 20-40 pairs on Stoltenhoff Island. These estimates may be conservative; my impression is that Nightingale Buntings occur at similar densities to Lowland Buntings in coastal tussock on Inaccessible Island, which suggests a total population of some 4,000 pairs. This species qualifies as Vulnerable due to its small range (4 $\mathrm{km}^{2}$ ) under criterion $\mathrm{D}_{2}$.

In terms of the revised taxonomy, Wilkins' Bunting is endemic to Nightingale Island. It occurs in close association with copses of Phylica trees, which are localized, with the largest concentration around the Ponds (Figure 3). Elliott (1957) estimated a population of some 30 pairs in the 1950s, a figure that Richardson (1984) concurred with in the 1970s. During 10 days on Nightingale Island in November 1999 I mapped the distribution of Phylica woodland, and estimated some 50 pairs associated with $<10$ ha of woodland. It is clear that the population is very small, and probably always has been. It qualifies as Endangered under criterion Di (very small population; $<250$ mature individuals). The species is vulnerable to habitat loss, including wood-cutting during seabird harvesting trips to Nightingale by Tristan islanders (Elliott 1957, Richardson 1984). This practice should be disallowed. In 2001 a freak storm caused extensive damage to buildings on Tristan, and flattened areas of Phylica trees on Nightingale. Since then, several one-day tourist visits have not seen Wilkins' Buntings on the island. A more thorough survey is required to ascertain the impact of this storm. Should the population have crashed, the species could qualify as Critically Endangered in terms of criterion $\mathrm{B}_{1}+3$ (small range and fluctuating population). In the longer term, regular monitoring of the population may be required.

\section{Management implications}

Inaccessible Island is a strict nature reserve and, together with Gough Island, forms part of a natural World Heritage Site (Ryan and Glass 2001). The island has a management plan which inter alia places strict controls on visits and the importation of materials to the island, specifically to reduce the risk of introducing alien organisms, including rodents and other potential predators (Ryan and Glass 2001). Nightingale Island lacks formal protection. It is visited regularly by people from Tristan, and there are several small huts on the island that are used during visits to exploit local seabird populations (Wace and Holdgate 1976, Richardson 1984). In addition to protection for Phylica copses on the island, there needs to be greater control on the import of materials to prevent the inadvertent introduction of alien organisms. A management plan currently being produced for Nightingale Island should include these measures. Both islands already have introduced populations of several invasive plants and invertebrates (Roux et al. 1992, Ryan 2007), some of which have the potential to affect natural systems. Plans to remove these species, where feasible, warrant support.

Nesospiza represents a fascinating example of evolution in action, especially on Inaccessible Island (Ryan et al. 2007). It is tempting to manipulate the system to test evolutionary theories, but great care must be taken not to influence natural processes. It would be unethical to deliberately move birds or eggs between habitats or between islands. Every effort should be made to allow the current evolutionary processes to continue, including reducing the impacts of introduced species on natural systems.

\section{Acknowledgements}

Permission to work at the Tristan islands was kindly granted by the Administrator and Island Council of Tristan da Cunha. Ovenstone Fishing, the South African Department of Environmental Affairs and Tourism and Tristan's Natural Resources Department provided 


\section{$1 \mathrm{~km}$}

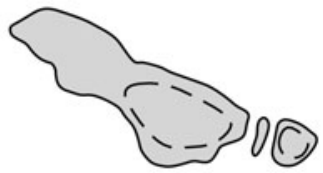

\section{Stoltenhoff}

\section{Spartina tussock}

Phylica woodland
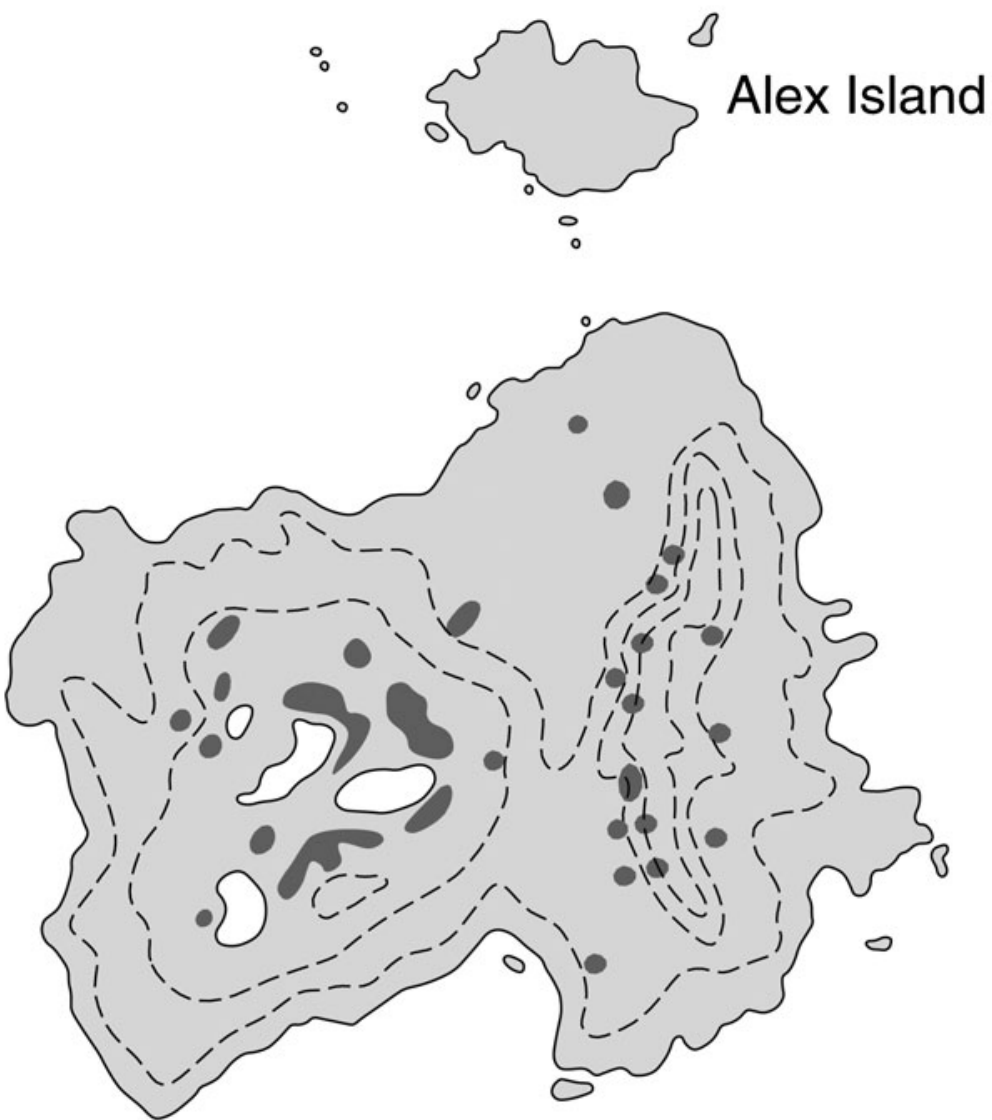

Nightingale Island

Figure 3. Nightingale Island, showing the approximate distribution of Phylica arborea woodland (dark shading), which is required habitat for Wilkins' Bunting Nesospiza wilkinsi. White areas on the main island are the four ponds; dashed lines show approximate $150 \mathrm{~m}$ contours. 
invaluable logistical support; I am especially grateful to James Glass, Cecil Poleman and Clarence October. Coleen Moloney, Cliff Dorse and Barry Watkins gave assistance in the field. Wayne Delport, Tyron Grant and Paulette Bloomer conducted genetic analyses on Nesospiza samples. This manuscript was improved by comments from Martim de Melo and an anonymous referee. Financial support was obtained from the National Geographic Society, the U.K. Overseas Territories Environment Programme, the Department of Science and Technology, the South African National Research Foundation and the University of Cape Town.

\section{References}

Abbott, I. (1978) The significance of morphological variation in the finch species on Gough, Inaccessible and Nightingale Islands, South Atlantic Ocean. J. Zool., Lond. 184: 119-125.

Barrow, K. M. (1910) Three years in Tristan da Cunha. London: Skeffington.

BirdLife International (2004) Threatened birds of the world. Cambridge, U.K: BirdLife International.

Bourne, W. R. P. and David, A. C. F. (1981) Nineteenth century bird records from Tristan da Cunha. Bull. Brit. Ornithol. Club 101: $247^{-256}$.

Cabanis, J. L. (1873) Ueber zwei neue Finkenarten des Berliner Museums: Crithagra insularis and Nesospiza acunhae von Tristan d'Acunha. J. Ornithol. 21: 152-155.

Carmichael, D. (1818) Some account of the island of Tristan da Cunha and of its natural productions. Trans. Linn. Soc. Lond. 12: 483-513.

Collar, N. J. (1997) Taxonomy and conservation: chicken and egg. Bull. Brit. Ornithol. Club 117: 122-136.

Collar, N. J. and Stuart, S. N. (1985) Threatened birds of Africa and related islands. The ICBP/IUCN Red Data Book. Third edition. Cambridge, U.K: International Council for Bird Preservation and IUCN.

Cuthbert, R. J. and Hilton, G. M. (2004) Introduced House Mice Mus musculus: a significant predator of endangered and endemic birds on Gough Island, South Atlantic Ocean? Biol. Conserv. 117: 483-489.

Dupetit Thouars, A. (1811) Description abrégée des iles de Tristan d'Acunha et Equisse de la Flore de l'isle de Tristan
d'Acunha. Pp. 1-44 in Mélanges de Botaniques et des voyages. Paris: Arthus Bertrand.

Elliott, H. F. I. (1957) A contribution to the ornithology of the Tristan da Cunha group. Ibis 99: 545-586.

Fraser, M. W. and Briggs, D. J. (1992) New information on the Nesospiza buntings at Inaccessible Island, Tristan da Cunha, and notes on their conservation. Bull. Brit. Ornithol. Club 112: 191-205.

Hagen, Y. (1952) The birds of Tristan da Cunha. Res. Norw. Sci. Exped. Tristan da Cunha 1937-1938 20: 1-248.

Lack, D. (1947) Darwin's Finches. Cambridge, U.K.: Cambridge University Press.

Lowe, P. R. (1923) Notes on some land birds of the Tristan da Cunha group collected by the Quest Expedition. Ibis 5: 511-529.

McKitrick, M. C. and Zink, R. M. (1988) Species concepts in ornithology. Condor 90: 1-14.

Moseley, H. N. (1892) Notes by a naturalist. An account of observations made during the voyage of H.M.S. Challenger. London: Macmillan.

Ollier, C. D. (1984) Geomorphology of the South Atlantic volcanic islands. Part I: the Tristan da Cunha group. Z. Geomorphol. 28: $367-382$.

Phillimore, A. B. and Owens, I. P. F. (2006) Are subspecies useful in evolutionary and conservation biology? Proc. R. Soc. Lond. B 273, 1049-1053.

Rand, A. L. (1955) The origin of landbirds of Tristan da Cunha, Nightingale and Inaccessible Islands. Fieldiana Zool. 37: 139-166.

Richardson, M. E. (1984) Aspects of the ornithology of the Tristan da Cunha group 
and Gough Island, 1972-1974. Cormorant 12: 122-201.

Roux, J. P., Ryan, P. G., Milton, S. J. and Moloney, C. L. (1992) Vegetation and checklist of Inaccessible Island, central South Atlantic Ocean, with notes on Nightingale Island. Bothalia 22: 93-109.

Ryan, P. G. (1992) The ecology and evolution of Nesospiza buntings. Unpubl. Ph.D. thesis, University of Cape Town (3oopp).

Ryan, P. G. (2001) Morphological heritability among a hybrid bunting complex: Nesospiza at Inaccessible Island. Condor 103: 429-438.

Ryan, P. G. (2007) Field guide to the animals and plants of Tristan da Cunha and Gough Island. Newbury: Pisces Publications.

Ryan, P. G. and Glass, J. P. (2001) Inaccessible Island Nature Reserve management plan. Edinburgh, Tristan da Cunha: Government of Tristan da Cunha.

Ryan, P. G., Moloney, C. L. and Hudon, J. (1994) Color variation and hybridization among Nesospiza buntings on Inaccessible Island, Tristan da Cunha. Auk 111: 314-327.

Ryan, P. G., Bloomer, P., Moloney, C. L., Grant, T. and Delport, W. (2007) Adaptive speciation in South Atlantic island finches. Science 315: 1420-1423.

Wace, N. M. and Holdgate, M. W. (1976) Man and nature in the Tristan da Cunha Islands. Int. Union Conserv. Nature and Natural Res. Monogr. 6: 1-114.

Zink, R. M. (1997) Species concepts. Bull. Brit. Ornithol. Club 117: 97-109.

Zink, R. M. (2004) The role of subspecies in obscuring avian biological diversity and misleading conservation policy. Proc. $R$. Soc. Lond. B 271, 561-564.

\section{PETER G. RYAN}

DST-NRF Centre of Excellence, Percy FitzPatrick Institute of African Ornithology, University of Cape Town, Rondebosch, 7701, South Africa; e-mail:peter.ryan@uct.ac.za 